\title{
[第37回総会シンポジウム追加発言]
}

\section{スラントホールコリメータとバイラテラル コリメータの画像とその評価}

\author{
山形大学医学部附属病院放射線部
}

高 橋 和。栄

\section{1.はじめに}

近年, 心臟核医学の発達はめざましく，目的に応じコ リメータの種類も多様である。 スラントホールコリメー タ,バイラテラルコリメータも, そのひとつである. 私 に与えられたテーマは, との2つのコリメータによる面 像とその評価である. 一部の施設で断㬝像などに応用さ れているが, 今回は，私どもが日常使用している範国に ついてましめてみた.

スラントホールコリメータは, ホールの向き为 $30^{\circ}$ 㖽 いており，その方向を白由に回転できる構造になってい る.

バイラテラルコリメータは, 視野を 2 分する中心線に 向って, 各々 $30^{\circ}$ 内側て傾けたコリメータである。 ホー ルそのものは，いづれも平行型である.

その基本性能を Fig. 1 亿示した. システム半值幅で 棓う $0^{\circ}$ は, ラインソースさコリメータのホールの傾き が平行， $90^{\circ}$ は，その直角方向を示す. $90^{\circ}$ 方向でシステ ム半值幅が貫くなるのは, シンチレータへの斜入による ものと考える. 感度は，私どもが常用している中感度八 ラレルコリメータを基準にした。

\section{2. スラントホールコリメータによる画像}

2.1 スラントホールコリメータの特徴

1) 低感度 (相刘感度 0.6 ) である。

2) 画像に歪肪ある.

3）密着した状態で斜位像が得られる.

页は、 Fig. 2 に示すようにコリメータが做いているた め,ささりられない現象である。同様のととは, バィラ คルコリ×ータにも音える. また, 乙の傾きによって, 検出器を胸壁て密着させた状態て，RAO $30^{\circ}$ ，MLAO の 像が得られるようれなる。

私どもは, このほか検出器の傾斜とコリメータの回転 乙, RAO $30^{\circ}$, Ant., LAO 45, lt-Lat. の像を得ているの て, その方向を Fig. 3 亿図示する: コリメータ面を胸壁 に水平に置いて RAO $30^{\circ}$ の像为, 左側に $30^{\circ}$ 傾斜させ $\left\ulcorner\right.$ Ant. O像が得ら杍。次に、コリメータを $180^{\circ}$ 回転 し, 左側て $15^{\circ}$ 傾斜してLAO $45^{\circ}$ の像か, 同しく左側 て 60傾斜させてlt-Lat. の像が得られる。乙の場合，貟 者ますへて仰虏位固定しもる。

\section{2 スラントホールコリメータの評価}

$\mathrm{RAO} 30^{\circ}$ 性, 有心系では, 存室の流出路为広了観祭て き，左心系で，左室の長軸が最む長及見 える方向である. First pass 法による RAO $30^{\circ}$ の䠦体例を Fig. 4 亿示与. 図の左側方

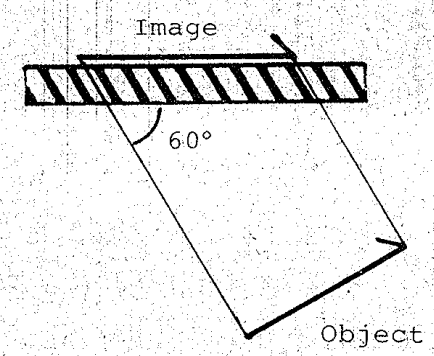

Fig. 2. 画像の歪
Fig. 1. 基 未 性, 能

IIIVWn

Bilateral

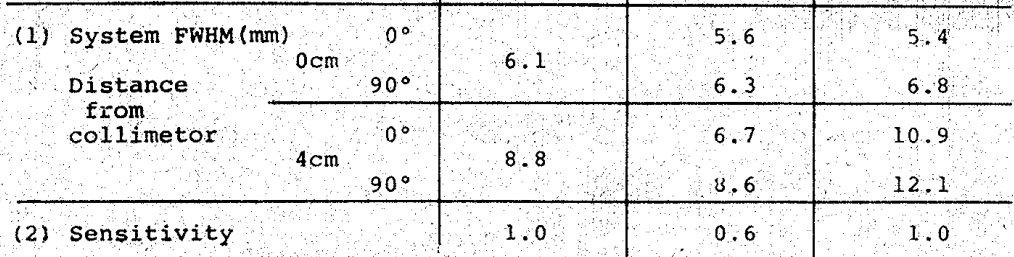




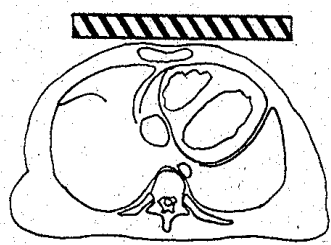

RAO $30^{\circ}$

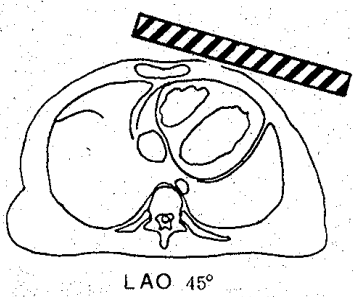

Fig. 3. スラントホールコリメー夕の ポシショニング

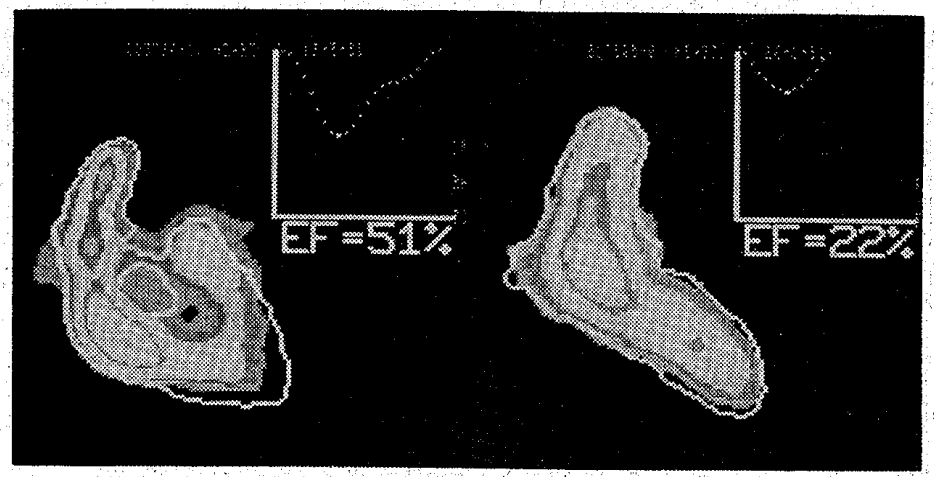

Fig. 4. 臨床例 左: 右室, 在: 左室

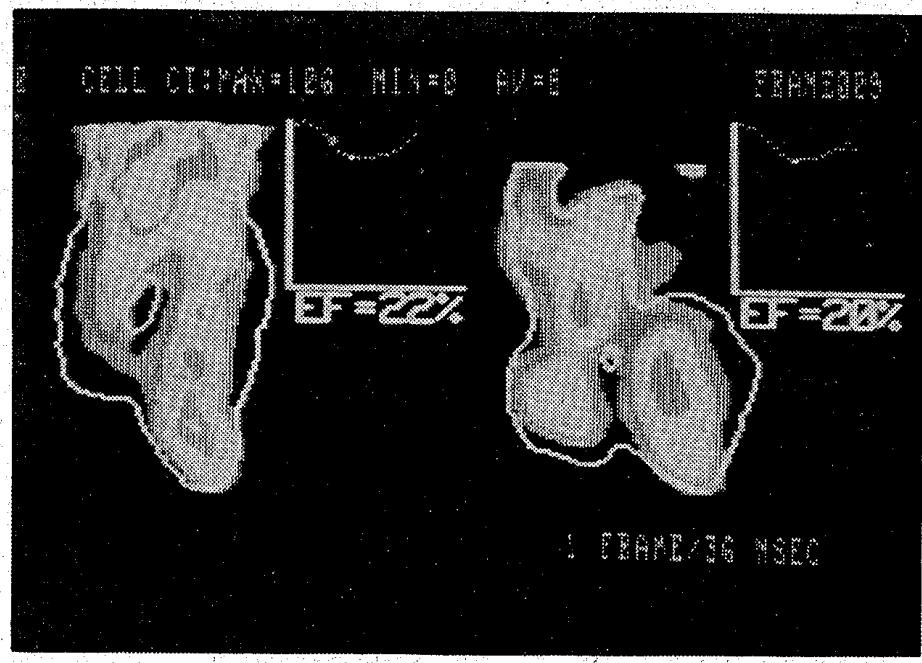

Fig. 5. 臨木例 左: MLAO, 在: LAO

右心系，存側が左心系でその特長が䈨くわかる。

MLAO は, 左房と左室汃明膫飞分離して描加れる。 たLAOでは，ゆがんで描出された心室中隔も，MLAO では，正常に近い長さに描出される。牙衡時法による,

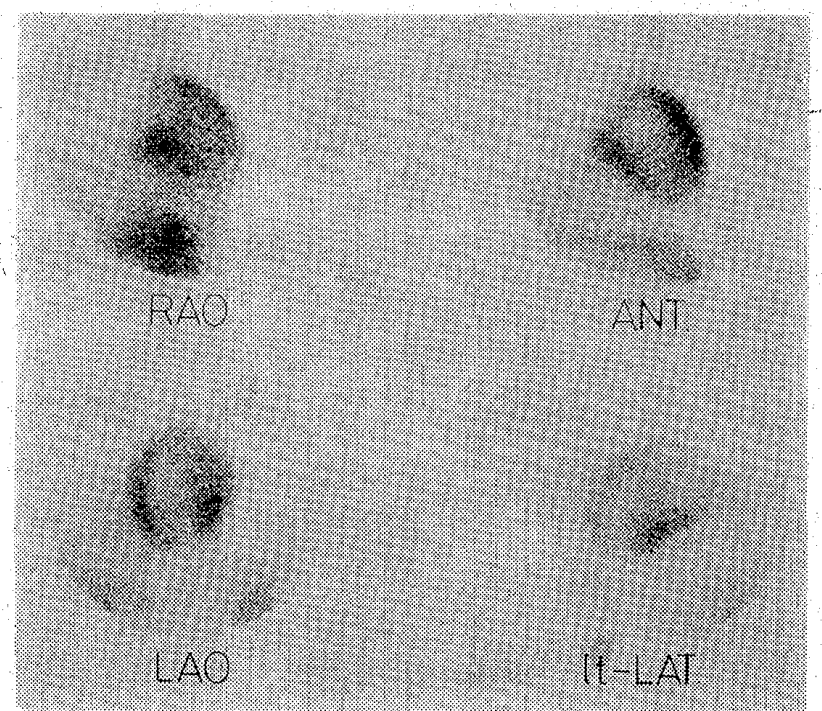

Fig. 6. Fig. 3 亿よ子臨床例

MLAO, LAO O臨床例老 Fig. 5 亿示す。左側か MLAO, 有側か LAO で, MLAO の像では，前边 の特長が良くわかる。

從来のコリメータでは, RAO $30^{\circ}$ p MLAO 方阎は, 検出器と胸壁の距離が大きくなり, 感度 之分解能の低下があった. スラントホールコリメ 一夕は，胸壁亡密着して，てれらの像を得るため, 感度と分解能の低下はない。

また，患者を仰卧位值定のまま，検出器の傾 斜と、コリメータの回転だけで, RAO $30^{\circ}$, Ant., LAO $45^{\circ}$, It-Lat. 像が得られる.とのため, 像の 再現性も良く，撮影時間も短しなどの利点を有す る.とのととは, 負荷心筋シンチグラムで ${ }^{201 T l}$ の wash out を定量化する場合，特に有效であっ た。臨床例を Fig. 6 亿示す. Fig. 3 の方法で撮 影した心筋シンチグラムで, 左上が RAO $30^{\circ}$, 右 上がAnt, 左下が LAO $45^{\circ}$ ，右下が lt-Lat.であ 3.

\section{3 小 括}

スラントホールコリメータは，㭧者を動かすと となく, 短時間に, RAO $30^{\circ}$, Ant., LAO $45^{\circ}$, MLAO, lt-Lat. の像が得られる. また再現性も極 めて良い。心蔵核医学には，必須のコリメータで あると考える。

\section{3. バイラテラルコリメータによる} 画像

3.1 バイラテラルコリメータの特徵

1）分解能が劣る. 
2) 画像に查がある.

3) 同時 2 方向の画像汃同一視野飞得られる.

コyメー夕面力胸照乙平行て, $\mathrm{RAO} 30^{\circ}, \mathrm{LAO} 30^{\circ}$ ○ 像力, 左側飞 $30^{\circ}$ の傾斜て Ant., $\mathrm{LAO} 60^{\circ}$ の同時 2 方向 の像力゙得られる。

\section{2 バイラテラルコリメータの評価}

RAO $30^{\circ}$, LAO $30^{\circ}$ o臨床例を Fig. 7 に示す. First pass 法による左等像で，壁のほぼ全周が観察てきる.し

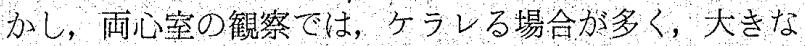
短所となっている.とれは,コリメータのホールの值き が合計 $60^{\circ}$ と浅いしとが原因である. 検出器と腧壁を離 せは，ケラレは少なくなるが，分解能はさらに低下する。 バィラテラルコリメータはまた， 2 方向の像が同一視 野にあるため，抬大モードが使用できなし，とのしとは， 1万问あたりのマトリックス数か少なくなり, 駆出率の ROI の決定, 及ひ, 壁運動の観察がむずかしくなる短所 につなかる。

しかし，同時 2 万问の魅力は大きく，私ともは，コり

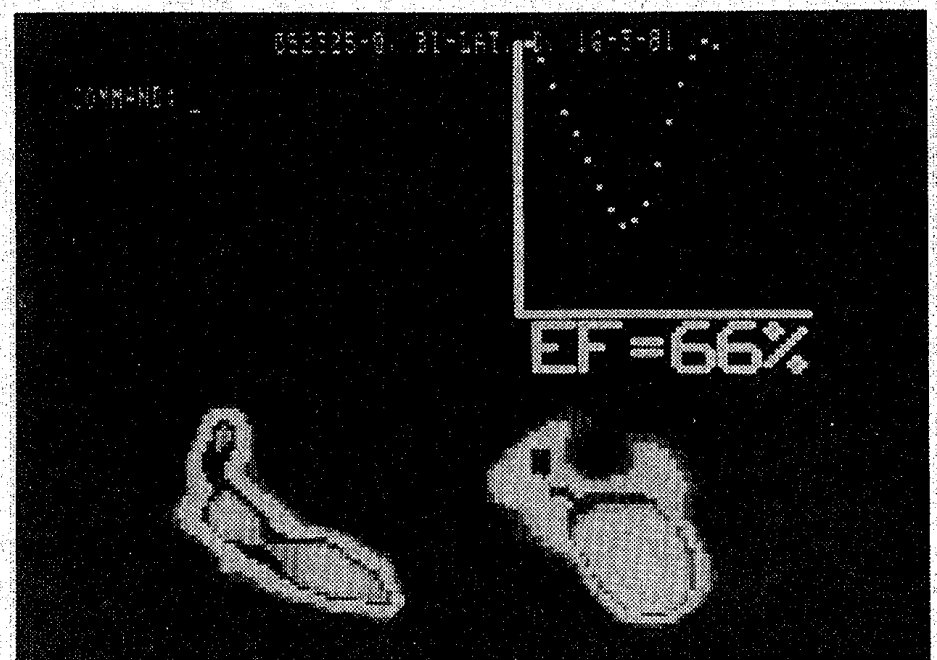

Fig. 7. 左: $\mathrm{RAO} 30^{\circ}$, 右: $\mathrm{LAO} 30^{\circ}$
Table 1. ホール角度 $30^{\circ}$ と $45^{\circ}$ の比較

\begin{tabular}{|c|c|c|}
\hline 8 & $30^{\circ}$ & $45^{\circ}$ \\
\hline 深さ $4 \mathrm{~cm} 0$ 視野 & $4.6 \mathrm{~cm}$ & $8.0 \mathrm{~cm}$ \\
\hline 最大視野の深さ & $16.5 \mathrm{~cm}$ & $9.5 \mathrm{~cm}$ \\
\hline 霆 & 1. 15 倍 & 1. 41 倍 \\
\hline FWHM & 1.00 & 1.23 \\
\hline
\end{tabular}

(視野 $38 \mathrm{~cm}$ )

メータのホールの傾さを $30^{\circ}$ 力ら $45^{\circ}$ に変える方法を, 検討してける.その結果は, Table 1亿示すように, 浅 い位直の視野が広くなる。また，最大視野の深さも約 $9.5 \mathrm{~cm}$ しなり，はは心蔵の中心位置と一致する. 一方, 正，分解能などは办化すると思われるが， $90^{\circ} 2$ 方向の 像が得られる魅力は，こ机飞も増して大きいとおすわれ 3 .

3.3 小 括

バィラララルコリメータは,ケラレ，分解能などの問 題点はあるが，同時 2 方向の鬿力は大きい。コリメータ 乙周过機器の改良为進むなら，現在以上に有用な コリメータになると考える.

\section{4. 結 論}

スラントホールコリメータは, 㛒時間に, 再現 性の良し，多方向の像が得られ，心蔵核医学には; 必須のるリメータであると考える.

一力, バイラテラルコリメータは, 同時 2 方间 の像の利点はあるか，ヶラレ，分解能などの問題 点があった. 今後, 改良されるなら有用なコリメ 一夕になる60し考える.

最後に，発表の機会を与えていただいた第37回 日本放射線技術学会役貣の皆様し深く感謝します. 